\title{
Molecular Serotyping of Escherichia coli O26:H11
}

\author{
Lisa M. Durso, James L. Bono, and James E. Keen* \\ USDA, ARS, U.S. Meat Animal Research Center, P.O. Box 166, State Spur 18D, \\ Clay Center, Nebraska 68933
}

Received 29 October 2004/Accepted 14 March 2005

\begin{abstract}
Serotyping is the foundation of pathogenic Escherichia coli diagnostics; however, few laboratories have this capacity. We developed a molecular serotyping protocol that targets, genetically, the same somatic and flagellar antigens of $E$. coli $026: H 11$ used in traditional serotyping. It correctly serotypes strains untypeable by traditional methods, affording primary laboratories serotyping capabilities.
\end{abstract}

Human infections with Escherichia coli O26:H11 and O26: $\mathrm{H}$-untypeable (H-) or H-nonmotile (NM) strains are associated with diarrhea, hemorrhagic colitis, and hemolytic uremic syndrome $(2,33)$. Depending on virulence factors, E. coli O26 is classified as enterohemorrhagic (EHEC) or enteropathogenic (EPEC). The E. coli O26 serotype, first reported to cause pediatric EPEC diarrhea (18), has been isolated from EHEC outbreaks in Europe $(1,13,15,31)$, South America $(22,28)$, and Japan (10, 11); from sporadic cases in Canada (12), Australia (7), and the United States (4); and from sick $(14,21)$ and healthy $(20,25,32)$ livestock. E. coli O26 is the most frequently isolated non-O157 Shiga-toxigenic E. coli (STEC) associated with human clinical illness (3), and E. coli $\mathrm{O} 26: \mathrm{H} 11$ is the clinically most important and epidemiologically most predominant EPEC and EHEC O26 serotype $(2,33)$.

Conventional E. coli $\mathrm{O}: \mathrm{H}$ serotyping by agglutination of somatic and flagellar antigens by the use of anti-E. coli polyclonal antiserum is time consuming, expensive, and available only in a small number of reference laboratories $(3,33)$. E. coli $\mathrm{O}: \mathrm{H}$ serotyping of pathogens may be required, however, for proper diagnosis and treatment, to maximize an isolate's usefulness for surveillance and to determine overall disease trends (33). PCR-based methodologies to detect or identify pathogenic E. coli $\mathrm{O} 26$ strains have targeted virulence genes such as Shiga toxin (stx) (9) and intimin (eae) $(12,27)$, flagellar $\mathrm{H}-$ antigen genes fliC-fliA (17), and the O-antigen $\mathrm{O} 26 w z x$ genes $(5,16,23)$. PCR methods targeting $\mathrm{O} 26 \mathrm{O}$-antigen or $\mathrm{H} 11 \mathrm{fliC}$ genes could substitute for serotyping $(5,24)$. We therefore developed a molecular serotyping method to target the somatic and flagellar antigens and to allow clinical laboratories to accurately serotype E. coli as $\mathrm{O} 26$ and/or H11 by multiplex PCR (mPCR).

A $12-\mathrm{kb}$ region of the E. coli O26:NM O-antigen operon from bovine fecal isolate SB6629 was sequenced (accession number AY763106); this region is identical to the corresponding region of the O26 O-antigen operon sequence (AF529080) reported by D'Souza et al. (6). Twenty sets of E. coli O26 O-antigen specific primers were synthesized and evaluated against a small panel of E. coli $\mathrm{O} 26$ and non-O26 E. coli

\footnotetext{
* Corresponding author. Mailing address: USDA, ARS, U.S. Meat Animal Research Center, P.O. Box 166, State Spur 18D, Clay Center, NE 68933. Phone: (402) 762-4343. Fax: (402) 762-4375. E-mail: keen@email.marc.usda.gov.
}

isolates. One primer set, $w z x-w z y \mathrm{O} 26 \mathrm{~F}$ and $w z x-w z y \mathrm{O} 26 \mathrm{R}$, targeting the $\mathrm{O} 26 w z x$-wzy genes (O-antigen flippase and polymerase, respectively), had $100 \%$ sensitivity and specificity and a suitable amplicon size.

The E. coli $\mathrm{H} 7$ flagellum gene sequence is heterogenous, and $\mathrm{fli}_{\mathrm{H} 7}$ sequence of the $\mathrm{O} 157$ serogroup is distinct from $\mathrm{fliC}_{\mathrm{H} 7}$ sequence of other O serogroups (29). To determine H11 flagellum sequence heterogeneity across different $\mathrm{O}$ serogroups (35), the $\mathrm{fli}_{\mathrm{H} 11}$ genes of $20 \mathrm{H} 11 \mathrm{E}$. coli isolates comprising five O serogroups were sequenced (accession numbers AY906918 to AY906937). Eighteen of these sequences were identical to those previously reported $(34,35)$. Two E. coli O26:H11 strains had one and two nonsynonymous substitutions, respectively, compared to the consensus $f l i C_{\mathrm{H} 11}$ sequence. Thus, we chose to use $f l i C_{\mathrm{H} 11}$ primers designed by Wang et al. (30) for our assay.

The primers for $E$. coli $\mathrm{O} 26: \mathrm{H} 11$ molecular serotyping were $w z x-w z y \mathrm{O} 26 \mathrm{~F}$ (5'-AAATTAGAAGCGCGTTCATC), wzx-wzy O26R (5'-CCCAGCAAGCCAATTATGACT), fliCRH11-1 (5'-ACTGTTAACGTAGATAGC) (30), and fliCRH11-2 (5' TCAATTTCTGCAGAATATAC) (30). Cells were prepared by diluting overnight Trypticase soy broth cultures 1:10 with reagent grade water. The $20 \mu \mathrm{l}$ PCR used $1 \mu \mathrm{l}$ of template and 0.5 U HotStarTaq (QIAGEN, Valencia, CA). The PCR mix contained concentrations of $500 \mu \mathrm{M}$ per nucleotide, $600 \mathrm{nM}$ for each primer, and $4.5 \mathrm{mM} \mathrm{MgCl}_{2}$. Thermocycler conditions were $95^{\circ} \mathrm{C}$ for $15 \mathrm{~min}, 35$ cycles of $94^{\circ} \mathrm{C}$ for $60 \mathrm{~s}, 56^{\circ} \mathrm{C}$ for $60 \mathrm{~s}$, and $72^{\circ} \mathrm{C}$ for $60 \mathrm{~s}$, and a final elongation of $72^{\circ} \mathrm{C}$ for $10 \mathrm{~min}$. Amplicons were visualized by electrophoresis on a $2 \%$ agarose gel run at $100 \mathrm{~V}$ for $2 \mathrm{~h}$, stained with ethidium bromide, and digitally photographed. Isolates positive for the O26 and H11 alleles displayed bands of 596 bp and 224 bp, respectively (Fig. 1). We applied the E. coli $\mathrm{O} 26 / \mathrm{H} 11 \mathrm{mPCR}$ to three diverse bacterial isolate panels to evaluate assay performance. Panel I was composed of 344 isolates: 322 diverse E. coli of known $\mathrm{O}$ and/or $\mathrm{H}$ serotype (including $31 \mathrm{E}$. coli $\mathrm{O} 26: \mathrm{H} 11$ strains) of human, animal, insect, and environmental origins, and 22 non-E. coli. This panel was used to generate mPCR diagnostic sensitivity and specificity estimates. (A detailed list of the strains used is available at http://www.ars.usda.gov/sp2User Files/Place/54380570/AHRU/E.coli/AEM_Durso_isolate_list .pdf). The $\mathrm{O} 26$ and $\mathrm{H} 11$ serotype status of 42 E. coli strains comprising panel II was tested blindly (without knowledge of their conventional O:H serotype). Panel III, a subset of panel 


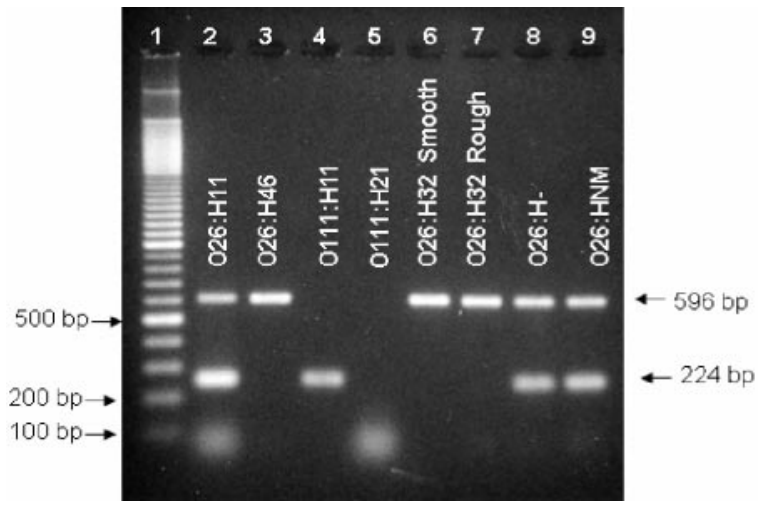

FIG. 1. Molecular serotyping of $E$. coli $\mathrm{O} 26: \mathrm{H} 11$ by multiplex PCR. Lane 1, molecular marker (100 bp); lane 2, H311b, O26 standard reference strain (E. coli O26:H11); lane 3, 5306-56 (E. coli O26:H46); lane 4, 88-4110 (E. coli O111:H11); lane 5, DEC 15C (E. coli O111: H21); lane 6, TWO7187a, O26 smooth (E. coli O26:H32); lane 7, TWO7187b, O26 rough (E. coli O26:H32); lane 8, 95.0256 (E. coli O26:H- untypeable); lane 9, TW04272 (E. coli O26:H nonmotile).

I composed of 35 E. coli $\mathrm{O} 26: \mathrm{NM}$ (34 eae positive, 1 eae negative) and $11 \mathrm{O} 26: \mathrm{H}-$ (10 eae positive, 1 eae negative) strains, was used to estimate the proportion of E. coli O26: $\mathrm{NM} / \mathrm{H}$ - strains that possess the $\mathrm{fli}_{\mathrm{H} 11}$ gene without expressing the H11 antigen. Although all reactions were run in the multiplex format, assay performance was measured separately for the $\mathrm{O} 26$ and $\mathrm{H} 11$ primer sets. Additionally, E. coli O26 strains were serologically confirmed as $\mathrm{O} 26$ by enzyme immunoassay using an anti-E. coli $\mathrm{O} 26$ murine monoclonal antibody (26), and E. coli $\mathrm{O} 26$ and $\mathrm{H} 11$ strains were assayed for the presence of stx1, stx2, and eae genes as previously described (19) (Table 1).

The E. coli $\mathrm{O} 26 / \mathrm{H} 11 \mathrm{mPCR}$ assay was $100 \%$ sensitive and specific based on reactions with the 344 panel I bacteria (Table 1). The assay correctly determined the O26 and H11 serotype of the 42 blind-panel E. coli strains (Table 2). All 35 E. coli O26: $\mathrm{NM}$ and 10 of 11 E. coli O26:H- strains in panel III were $\mathrm{fliC}_{\mathrm{H} 11}$ positive. These results are consistent with the findings of Zhang et al. (34), who noted that eae-positive E. coli O26:Hstrains belong to an $\mathrm{H} 11$ clonal complex. The $f l i C_{\mathrm{H} 11}$-negative E. coli $\mathrm{O} 26: \mathrm{H}$ - strain was eae negative and therefore not part of the H11 clonal complex. The mPCR assay also identified seven strains that had apparently been misserotyped or mislabeled with respect to $\mathrm{O} 26$ and/or H11 serotype. The mPCR and serotyping results for these seven strains initially appeared discordant. However, when these isolates were reserotyped by the E. coli Reference Center (University Park, PA), the revised results agreed with those of the mPCR O26/H11 assay. Importantly, molecular serotyping methods generate genotypic information, in contrast to traditional serotyping, which generates phenotypic (surface antigen expression) information. Thus, our E. coli $\mathrm{O} 26 / \mathrm{H} 11 \mathrm{mPCR}$ permits serotyping of "antigenically silent" strains which are $\mathrm{O}$ or $\mathrm{H}$ untypeable by conventional serotyping techniques. For example, our PCR assay serotyped rough lipopolysaccharide (O-antigen-free) colonies of blind-panel isolate TW07187 as O26, and identified the $f i C_{\mathrm{H} 11}$ gene in many $\mathrm{NM}$ and $\mathrm{H}-$ E. coli strains, in both $\mathrm{O} 26$ and non-O26 STEC.

In conclusion, the E. coli $\mathrm{O} 26 / \mathrm{H} 11 \mathrm{mPCR}$ assay accurately determined O26 and H11 serotypes of 364 conventionally serotyped E. coli strains by targeting the genes that encode the same somatic and flagellar antigens used in traditional serotyping. Furthermore, the mPCR assay serotyped E. coli isolates (such as rough $\mathrm{O} 26$ and nonmotile H11 strains) which were untypeable by conventional methods. Third, we found that 45 out of 46 STEC and non-STEC O26:NM/H- strains were $\mathrm{fli}_{\mathrm{H} 11}$ positive, analogous to the case of STEC O157:NM strains, which almost always possess the $f i C_{\mathrm{H} 7}$ gene (8). Finally, the assay allowed for confirmation of $E$. coli $\mathrm{O} 26$ and H11 serotype.

Traditional E. coli O:H serotyping, which detects surface antigen expression, will remain important, but application of molecular serotyping techniques that detect their genetic analogues (counterparts) have some relative advantages. While molecular E. coli O:H serotyping may not be appropriate for all bacteriologic investigations, it is well suited for clinical diagnostic, research laboratory, or epidemiologic investigations.

TABLE 1 . Sensitivity and specificity estimates of E. coli $\mathrm{O} 26$ and H11 mPCR compared to traditional serotyping for 344 panel I bacteria $(322 \text { E. coli and } 22 \text { non-E. coli })^{a}$

\begin{tabular}{|c|c|c|c|}
\hline Measure & No. of strains used & Estimate & $\begin{array}{l}95 \% \text { Confidence } \\
\text { interval }\end{array}$ \\
\hline O26 sensitivity $(n=81)$ & $\begin{array}{l}48 \text { E. coli } \mathrm{O} 26 \text { eae }+, \text { stx } \\
29 \text { E. coli } \mathrm{O} 26 \text { eae }+, \text { stx } \\
2 \text { E. coli } \mathrm{O} 26 \text { eae }-, \text { stx }+ \\
2 \text { E. coli } \mathrm{O} 26 \text { eae-, stx }+\end{array}$ & 1.00 & $0.96-1.00$ \\
\hline O26 specificity $(n=260)$ & 238 non-O 26 E. coli $^{b}$ & 1.00 & $0.99-1.00$ \\
\hline H11 sensitivity $(n=38)$ & $\begin{array}{l}26 \text { E. coli } \mathrm{H} 11 \text { eae }+, \text { stx }+ \\
10 \text { E. coli } \mathrm{H} 11 \text { eae }+, \text { stx }- \\
2 \text { E. coli } \mathrm{H} 11 \text { eae }-, \text { stx }-\end{array}$ & 1.00 & $0.91-1.00$ \\
\hline H11 specificity $(n=164)$ & $\begin{array}{l}142 \text { non-H11 E. } \text { coli }^{d} \\
22 \text { non-E. } \text { coli }^{c}\end{array}$ & 1.00 & $0.98-1.00$ \\
\hline
\end{tabular}

${ }^{a}$ Data compiled from multiplex PCR reactions. See isolate list for data on which strains were used in each analysis (http://www.ars.usda.gov/sp2UserFiles/Place 154380570/AHRU/E.coli/AEM_Durso_isolate_list.pdf).

${ }^{b}$ Non-O26 E. coli includes 238 isolates of $\overline{1} 11$ different $\mathrm{O}$ serotypes and excludes three isolates for which $\mathrm{O}$ serotype data were unavailable.

${ }^{c}$ Non-E. coli includes 22 isolates of 17 closely related genera.

${ }^{d}$ Non-H11 E. coli includes 142 isolates of 51 different $\mathrm{H}$ serotypes and excludes all strains for which $\mathrm{H}$ serotype data were missing, all strains that did not react with any of the standard $\mathrm{H}$ antisera, and all nonmotile strains. 
TABLE 2. Comparison of E. coli O26 and H11 serotyping results obtained from traditional serotyping, O26-specific monoclonal antibody enzyme-linked immunosorbent assay, and molecular serotyping by $\mathrm{mPCR}$ for $42 \mathrm{E}$. coli strains tested in a blind panel (panel II)

\begin{tabular}{|c|c|c|c|c|c|}
\hline \multirow[t]{2}{*}{ Strain $^{a}$} & \multicolumn{2}{|c|}{$\begin{array}{l}\text { Result by } \\
\text { traditional } \\
\text { serotyping }\end{array}$} & \multirow{2}{*}{$\begin{array}{c}\text { Result by } \\
\text { MAb }^{b} \\
\alpha-\mathrm{O} 26\end{array}$} & \multicolumn{2}{|c|}{$\begin{array}{l}\text { Result by } \\
\text { molecular } \\
\text { serotyping }\end{array}$} \\
\hline & $\mathrm{O}$ & $\mathrm{H}$ & & $\mathrm{O} 26$ & H11 \\
\hline TW07867 & 15 & 11 & neg $^{d}$ & neg & + \\
\hline TW09156 & 26 & 11 & + & + & + \\
\hline TW07154 & 26 & 11 & + & + & + \\
\hline TW07622 & 26 & 11 & + & + & + \\
\hline TW07872 & 26 & 11 & + & + & + \\
\hline TW08637 & 26 & 11 & + & + & + \\
\hline TW08998 & 26 & 11 & + & + & + \\
\hline IBL 7922 & 26 & 11 & + & + & + \\
\hline IBL 8179 & 26 & 11 & + & + & + \\
\hline IBL 8479 & 26 & 11 & + & + & + \\
\hline IBL 8907 & 26 & 11 & + & + & + \\
\hline TW07705 & 26 & 11 & + & + & + \\
\hline IBL 8419 & 26 & 11 & + & + & + \\
\hline TW01209 & 26 & 32 & neg & + & neg \\
\hline TW07187 & 26 & 32 & + & + & neg \\
\hline TW01221 & 26 & 36 & + & + & neg \\
\hline CP-ALLG & 45 & 2 & neg & neg & neg \\
\hline CP-COU & 45 & 2 & neg & neg & neg \\
\hline CP-BALL & 45 & 2 & neg & neg & neg \\
\hline TW01686 & 70 & 11 & neg & neg & + \\
\hline TW08640 & 103 & 2 & neg & neg & neg \\
\hline TW08872 & 103 & 11 & neg & neg & + \\
\hline IBL 6582 & 103 & 25 & neg & neg & neg \\
\hline IBL 8234 & 111 & $\mathrm{NM}^{c}$ & neg & neg & neg \\
\hline IBL 8361 & 111 & NM & neg & neg & neg \\
\hline TW07926 & 111 & 8 & neg & neg & neg \\
\hline TW03810 & 111 & 11 & neg & neg & + \\
\hline TW05355 & 111 & 11 & neg & neg & + \\
\hline TW08114 & 118 & 16 & + & neg & neg \\
\hline TW08868 & 121 & 19 & neg & neg & neg \\
\hline IBL 5518 & 121 & 19 & neg & neg & neg \\
\hline IBL 6507 & 121 & 19 & neg & neg & neg \\
\hline TW01110 & 124 & 30 & neg & neg & neg \\
\hline IBL 6940 & 145 & NM & neg & neg & neg \\
\hline IBL 8235 & 145 & NM & neg & neg & neg \\
\hline IBL 7606 & 146 & 21 & neg & neg & neg \\
\hline IBL 7427 & 157 & 7 & neg & neg & neg \\
\hline IBL 8257 & 157 & 7 & neg & neg & neg \\
\hline IBL 8434 & 157 & 7 & neg & neg & neg \\
\hline IBL 8463 & 157 & 7 & neg & neg & neg \\
\hline IBL 8827 & 157 & 7 & neg & neg & neg \\
\hline IBL 9488 & 157 & 7 & neg & neg & neg \\
\hline
\end{tabular}

${ }^{a}$ Strains with TW prefix provided by T. Whittam, Michigan State University, East Lansing, MI; Strains with CP prefix provided by C. Park, Inova Fairfax Hospital, Falls Church, VA; strains with IBL prefix provided by V. Lockary, State of Idaho Bureau of Laboratories, Boise, ID.

${ }^{b}$ Enzyme-linked immunosorbent assay reactivity with anti-O26 monoclonal antibody (MAb) 12F5 (26).

${ }^{c}$ NM denotes nonmotile strain.

${ }^{d}$ neg, negative.

The E. coli $\mathrm{O} 26 / \mathrm{H} 11 \mathrm{mPCR}$ assay described here should allow laboratories to generate E. coli $\mathrm{O} 26$ and $\mathrm{H} 11$ serotype data using routine PCR techniques and readily available equipment, since few laboratories have the capacity for serotyping non-O157 STEC (33). The assay was designed to allow for the addition of other PCR targets, such as stx or eae. We optimized this assay for use with a pure bacterial culture; as with tradi- tional serotyping, it is not appropriate for application to complex sample matrices with mixed microbial flora.

Nucleotide sequence accession numbers. The nucleotide sequence for E. coli $\mathrm{O} 26$ for the NM O-antigen operon from bovine fecal isolate SB6629 is deposited in GenBank as AY763106. Nucleotide sequences for $20 \mathrm{E}$. coli fli $\mathrm{C}_{\mathrm{H} 11}$ strains are as follows: strain ATCC 35401, O serotype 78, AY906918; strain DEC 10J, O serotype 70, AY906919; strain P1331, O serotype 26, AY906920; strain H311B, O serotype 26, AY906921; strain 89-491, O serotype 26, AY906922; strain 88-353, O serotype 26, AY906923; strain 88-157, O serotype 26, AY906924; strain H19, O serotype 26, AY906925; strain DEC 9E, O serotype 26, AY906926; strain DEC 9D, O serotype 26, AY906927; strain DEC 9A, O serotype 26, AY906928; strain DEC 10E, O serotype 26, AY906929; strain DEC 10D, O serotype 26, AY906930; strain DEC 10C, O serotype 26, AY906931; strain DEC 10B, O serotype 26, AY906932; strain Su 4321, O serotype 13, AY906933; strain 88-41, O serotype 111, AY906934; strain DEC 10A, O serotype 26, AY906935; strain DEC 8D, O serotype 26, AY906936; strain CL5, O serotype 26, AY906937.

This work was supported, in part, by USDA CSREES NRI grant 2002-2239 (awarded to J.E.K.). We thank Sandy Fryda-Bradley, Ron Mlejnek, and Liz Ossian for outstanding technical assistance; Kevin Tennill for photographic assistance; Joan Rosch for secretarial assistance; and Tom Wittum from The Ohio State University, Columbus, $\mathrm{OH}$, Greg Siragusa from the USDA, ARS, Russell Research Center, Athens, GA, and anonymous reviewers for helpful comments on the manuscript. Bacterial isolates were kindly provided by C. Park, Inova Fairfax Hospital, Falls Church, VA; D. Francis, South Dakota State University, Brookings, SD; M. Doyle, University of Georgia, Athens, GA; D. Acheson, Food and Drug Administration, College Park, MD; J. Johnson, University of Minnesota Veterans Hospital, Minneapolis, MN; L. Riley, University of California, Berkeley, CA; T. Whittam, Michigan State University, East Lansing, MI; Centers for Disease Control and Prevention, Atlanta, GA; Texas Department of Health, Austin, TX; National Animal Disease Center, Ames, IA; and V. Lockary, State of Idaho Bureau of Laboratories, Boise, ID.

Product names are necessary to report factually on available data; however, the USDA neither guarantees nor warrants the standard of the product, and the use of the name by USDA implies no approval of the product to the exclusion of others that may also be suitable.

\section{REFERENCES}

1. Allerberger, F., A. W. Friedrich, K. Grif, M. P. Dierich, H. J. Dornbusch, C. J. Mache, E. Nachbaur, M. Freilinger, P. Rieck, M. Wagner, A. Caprioli, H. Karch, and L. B. Zimmerhackl. 2003. Hemolytic-uremic syndrome associated with enterohemorrhagic Escherichia coli O26:H infection and consumption of unpasteurized cow's milk. Int. J. Infect. Dis. 7:42-45.

2. Anjum, M. F., S. Lucchini, A. Thompson, J. C. D. Hinton, and M. J. Woodward. 2003. Comparative genomic indexing reveals the phylogenomics of Escherichia coli pathogens. Infect. Immun. 71:4674-4683.

3. Bettelheim, K. A. 2003. Non-O157 verotoxin-producing Escherichia coli: a problem, paradox, and paradigm. Exp. Biol. Med. 228:333-344.

4. Bopp, C. A., K. D. Greene, F. P. Downes, E. G. Sowers, J. G. Wells, and I. K. Wachsmuth. 1987. Unusual verotoxin-producing Escherichia coli associated with hemorrhagic colitis. J. Clin. Microbiol. 25:1486-1489.

5. DebRoy, C., E. Roberts, J. Kundrat, M. A. Davis, C. E. Briggs, and P. M. Fratamico. 2004. Detection of Escherichia coli serogroups O26 and O113 by PCR amplification of the $w z x$ and $w z y$ genes. Appl. Environ. Microbiol. 70:1830-1832.

6. D'Souza, J. M., L. Wang, and P. Reeves. 2002. Sequence of the Escherichia coli $\mathrm{O} 26 \mathrm{O}$ antigen gene cluster and identification of $\mathrm{O} 26$ specific genes. Gene 297:123-127.

7. Elliott, E. J., R. M. Robins-Browne, E. V. O'Loughlin, V. Bennett-Wood, J. Bourke, P. Henning, G. G. Hogg, J. Knight, H. Powell, D. Redmond, and Contributors to the Australian Paediatric Surveillance Unit. 2001. Nationwide study of haemolytic uraemic syndrome: clinical, microbiological, and epidemiological features. Arch. Dis. Child. 85:125-131.

8. Fields, P. I., K. Blom, H. J. Hughes, L. O. Helsel, P. Feng, and B. Swami- 
nathan. 1997. Molecular characterization of the gene encoding $\mathrm{H}$ antigen in Escherichia coli and development of a PCR-restriction fragment length polymorphism test for identification of E. coli O157:H7 and O157:NM. J. Clin. Microbiol. 35:1066-1070.

9. Gannon, V. P. J., R. K. King, J. Y. Kim, and E. J. Golsteyn Thomas. 1992 Rapid and sensitive method for detection of Shiga-like toxin-producing Escherichia coli in ground beef using the polymerase chain reaction. Appl. Environ. Microbiol. 58:3809-3815.

10. Hiruta, N., T. Murase, and N. Okamura. 2001. An outbreak of diarrhoea due to multiple antimicrobial-resistant Shiga toxin-producing Escherichia coli O26:H11 in a nursery. Epidemiol. Infect. 127:221-227.

11. Hoshina, K., A. Itagaki, R. Seki, K. Yamamoto, S. Masuda, T. Muku, and N. Okada. 2001. Enterohemorrhagic Escherichia coli O26 outbreak caused by contaminated natural water supplied by facility owned by local community. Jpn. J. Infect. Dis. 54:247-248.

12. Louie, M., S. Read, A. E. Simor, J. Holland, L. Louie, K. Ziebell, J. Brunton, and J. Hii. 1998. Application of multiplex PCR for detection of non-O157 verocytotoxin-producing Escherichia coli in bloody stools: identification of serogroups O26 and O111. J. Clin. Microbiol. 36:3375-3377.

13. McMaster, C., E. A. Roch, G. A. Willshaw, A. Doherty, W. Kinnear, and T. Cheasty. 2001. Verocytotoxin-producing Escherichia coli serotype O26:H11 outbreak in an Irish creche. Eur. J. Clin. Microbiol. Infect. Dis. 20:430-432.

14. Mercado, E. C., S. M. Rodríguez, A. M. Elizondo, G. Marcoppido, and V. Parreño. 2004. Isolation of Shiga toxin-producing Escherichia coli from a South American camelid (Lama guanicoe) with diarrhea. J. Clin. Microbiol. 42:4809-4811.

15. Misselwitz, J., H. Karch, M. Bielazewska, U. John, F. Ringelmann, G. Ronnefarth, and L. Patzer. 2003. Cluster of hemolytic-uremic syndrome caused by Shiga toxin-producing Escherichia coli O26:H11. Pediatr. Infect. Dis. J. 22:349-354.

16. Murinda, S. E., S. D. Baston, L. T. Nguyen, B. E. Gillespie, and S. P. Oliver 2004. Phenotypic and genetic markers for serotype-specific detection of Shiga toxin-producing Escherichia coli O26 strains from North America. Foodborne Path. Dis. 1:125-135.

17. O'Hanlon, K. A., T. M. G. Catarame, G. Duffy, I. S. Blair, and D. A McDowell. 2004. RAPID detection and quantification of E. coli $\mathrm{O} 157 / \mathrm{O} 26$ O111 in minced beef by real-time PCR. J. Appl. Microbiol. 96:1013-1023.

18. Orskov, F. 1951. On the occurrence of E. coli belonging to O-group 26 in cases of infantile diarrhoea and white scours. Acta Pathol. Microbiol. Scand. 29:373-378.

19. Paton, A. W., and J. C. Paton. 1988. Detection and characterization of Shiga toxigenic Escherichia coli by using multiplex PCR assays for $s_{1}, \mathrm{stx}_{2}, e a e A$, enterohemorrhagic $E$. coli $h l y A, r f b_{\mathrm{O} 111}$, and $r f b_{\mathrm{O} 157}$. J. Clin. Microbiol. 36:598-602.

20. Pearce, M. C., C. Jenkins, L. Vali, A. W. Smith, H. I. Knight, T. Cheasty, H. R. Smith, G. J. Gunn, M. E. J. Woolhouse, S. G. B. Amyes, and G. Frankel. 2004. Temporal shedding patterns and virulence factors of Escherichia coli serogroups O26, O103, O111, O145, and O157 in a cohort of beef calves and their dams. Appl. Environ. Microbiol. 70:1708-1716.

21. Pearson, G. R., K. J. Bazeley, J. R. Jones, R. F. Gunning, M. J. Green, A. Cookson, and M. J. Woodward. 1999. Attaching and effacing lesions in the large intestine of an eight-month-old heifer associated with Escherichia coli O26 infection in a group of animals with dysentery. Vet. Rec. 145:370-373.

22. Peixoto, J. C. C. S. Y. Bando, J. A. G. Ordonez, B. A. Botelho, L. R. Trabulsi, and C. A. Moreira-Filho. 2001. Genetic differences between Escherichia coli O26 strains isolated in Brazil and in other countries. FEMS Microbiol. Lett. 196:239-244.

23. Perelle, S., F. Dilasser, J. Grout, and P. Fach. 2004. Detection by 5 '-nuclease PCR of Shiga-toxin producing Escherichia coli O26, O55, O91, O103, O111, O113, O145 and O157:H7, associated with the world's most frequent clinical cases. Mol. Cell. Probes 18:185-192.

24. Prager, R., U. Strutz, A. Fruth, and H. Tschäpe. 2003. Subtyping of pathogenic Escherichia coli strains using flagellar $(\mathrm{H})$-antigens: serotyping versus fliC polymorphisms. Int. J. Med. Microbiol. 292:477-486.

25. Renter, D. G., S. L. Checkley, J. Campbell, and R. King. 2004. Shiga toxinproducing Escherichia coli in the feces of Alberta feedlot cattle. Can. J. Vet. Res. 68:150-153.

26. Rivera-Betancourt, M., and J. E. Keen. 2000. Murine monoclonal antibodies specific for lipopolysaccharide of Escherichia coli O26 and O111. Appl. Environ. Microbiol. 66:4124-4127.

27. Sharma, V. K. 2002. Detection and quantitation of enterohemorrhagic Escherichia coli O157, O111, and $\mathrm{O} 26$ in beef and bovine feces by real-time polymerase chain reaction. J. Food Prot. 65:1371-1380.

28. Vaz, T. M. I., K. Irino, M. A. M. F. Kato, Â. M. G. Dias, T. A. T. Gomes, M. I. C. Medeiros, M. M. M. Rocha, and B. E. C. Guth. 2004. Virulence properties and characteristics of Shiga toxin-producing Escherichia coli in São Paulo, Brazil, from 1976 through 1999. J. Clin. Microbiol. 42:903-905.

29. Wang, L., D. Rothemund, H. Curd, and P. R. Reeves. 2000. Sequence diversity of the Escherichia coli $\mathrm{H} 7 \mathrm{fli}$ C genes: implication for a DNA-based typing scheme for E. coli O157:H7. J. Clin. Microbiol. 38:1786-1790.

30. Wang, L., D. Rothemund, H. Curd, and P. R. Reeves. 2003. Species-wide variation in the Escherichia coli flagellin (H-antigen) gene. J. Bacteriol. 185:2936-2943.

31. Werber, D., A. Fruth, A. Liesegang, M. Littmann, U. Buchholz, R. Prager, H. Karch, T. Breuer, H. Tschäpe, and A. Ammon. 2002. A multistate outbreak of Shiga toxin-producing Escherichia coli O26:H11 infections in Germany, detected by molecular subtyping surveillance. J. Infect. Dis. 186:419-422.

32. Widiasih, D. A., N. Ido, K. Omoe, S. Sugii, and K. Shinagawa. 2003. Duration and magnitude of faecal shedding of Shiga toxin-producing Escherichia coli from naturally infected cattle. Epidemiol. Infect. 132:67-75.

33. World Health Organization. 1999. Zoonotic non-O157 Shiga toxin-producing Escherichia coli (STEC). W.H.O. Scientific Working Group Meeting, Berlin, Germany.

34. Zhang, W. L., M. Bielaszewska, J. Bockemuhl, H. Schmidt, F. Scheutz, and H. Karch. 2000. Molecular analysis of $\mathrm{H}$ antigens reveals that human diarrheagenic Escherichia coli $\mathrm{O} 26$ strains that carry the eae gene belong to the H11 clonal complex. J. Clin. Microbiol. 38:2989-2993.

35. Zhang, W. L., M. Bielaszewska, A. Liesegang, H. Tschape, H. Schmidt, M. Bitzan, and H. Karch. 2000. Molecular characteristics and epidemiological significance of Shiga toxin-producing Escherichia coli O26 strains. J. Clin. Microbiol. 38:2134-2140. 